\title{
Xenochlora meridionalis sp. nov. (Hymenoptera: Apidae), a new halictine bee from eastern Brazil as evidence of past connections between Amazonia and Atlantic Forest
}

\author{
Gabriel A.R. Melo(D), Luiz R.R. Faria(12), Leandro M. Santos $\mathbb{( \mathbb { D }}^{3}$

\begin{abstract}
1 Laboratório de Biologia Comparada de Hymenoptera, Departamento de Zoologia, Universidade Federal do Paraná. Caixa Postal 19020, 81531-980 Curitiba, PR, Brazil.

${ }^{2}$ Instituto Latino-Americano de Ciências da Vida e da Natureza, Universidade Federal da Integração LatinoAmericana. Avenida Tarquínio Joslin dos Santos 1000, Jardim Universitário, 85870-901 Foz do Iguaçu, PR, Brazil. ${ }^{3}$ Instituto de Formación Docente Salomé Ureña (ISFOODSU). Santo Domingo, República Dominicana. Corresponding author. Gabriel A.R. Melo (garmelo@ufpr.br)
\end{abstract}

http://zoobank.org/017E7DF5-862E-4E9D-9423-752DF0B451F2

\begin{abstract}
We describe a new species of the bee genus Xenochlora Engel, Brooks \& Yanega, 1997, X. meridionalis sp. nov., based on a single female collected in the coastal forests of southeastern Brazil, in the state of Espírito Santo. The disjunct distribution exhibited by Xenochlora, with species in northern South America and in the Atlantic Forest of eastern Brazil, is discussed in light of current knowledge about other taxa with similar distribution pattern.
\end{abstract}

KEY WORDS. Augochlorini, Halictidae, Neotropical, taxonomy, systematics.

\section{INTRODUCTION}

Xenochlora Engel, Brooks \& Yanega, 1997 is a rare genus of halictine bees until recently assumed to be restricted to the Amazon Basin and the Guiana shield (Engel et al. 1997, Santos and Melo 2013). The genus comprises four species: X. ianthina (Smith, 1861), X. nigrofemorata (Smith, 1879), X. chalkeos Engel, Brooks \& Yanega, 1997 and X. ochrosterna Engel, Brooks \& Yanega, 1997. Specimens of Xenochlora are rarely collected, and the entire genus is known only from a few females and a single male of $X$. nigrofemorata (Santos and Melo 2013). Nests of Xenochlora are built by females in dead wood, notably small dead branches hanging on the understory vegetation, and can be inhabited by single or multiple females (Smith 1861, Tierney et al. 2008). Multifemale nests are regarded to exhibit parasocial behavior, and a temporal switch between semisocial, eusocial and possibly communal phases was also proposed to occur within the genus (Tierney et al. 2008).

Within the Augochlorini, Xenochlora has been considered as closely related to Megalopta Smith, 1853 (Engel et al. 1997, Engel 2000, Tierney et al. 2012, Gonçalves 2016). In a recent molecular and morphological phylogenetic analysis of the extant Augochlorini, Megalopta was recovered as a paraphyletic group, as Megalopta atra Engel, 2006 appears in a clade with Xenochlo$\mathrm{ra}$, forming the sister group of the other species of Megalopta
(Gonçalves 2016). Reconstructing the phylogenetic history of Xenochlora, Megalopta, Megaloptidia Cockerell, 1900, Megommation Moure, 1943 and related genera is essential to understand the evolution of dim-light foraging in the tribe Augochlorini, which yet is possible to be interpreted in different ways (see Tierney et al. 2012, Gonçalves 2016).

In 2013, during fieldwork of a study on orchid bees at Reserva Natural Vale (Coswosk et al. 2018), one female of Xenochlora was unexpectedly caught in the scent traps. A preliminary comparison with available material suggested that it belonged to an undescribed species. More recently, Nemésio et al. (2016) recorded the genus in the same locality, Reserva Natural Vale, from the study of a female previously deposited in the Coleção Entomológica da Reserva Natural Vale (CERNV). They even considered the possibility of this individual to belong to a new undescribed species.

We herein describe a new species of Xenochlora from a large remnant of Atlantic Forest, collected in 2013. This is the first species occurring outside of Amazonian Formations at northern South America.

\section{MATERIAL AND METHODS}

The holotype was collected in the Reserva Natural Vale, a large remnant of Brazilian Atlantic forest, encompassing ca. 
22,700 ha in northern Espírito Santo state, southeastern Brazil (Lopes and Mello-Silva 2014). This reserve and Reserva Biológica Sooretama (ca. 24,000 ha) are recognized as the last Tabuleiro Forest massif in northern Espírito Santo (Amorim 1984, Silva 2014). Tabuleiro forests (Floresta Ombrófila Densa de Terras Baixas sensu Veloso et al. 1991) have distinctive physiognomic and floristic characteristics (e.g., Peixoto et al. 2008) and share many plant taxa with the Amazon Forest, including several species with disjunct distribution between Amazon and Atlantic forests (reviewed in Rolim et al. 2016).

The terminology for the external morphology follows Eickwort (1969), Engel (2000) and Michener (2007), except for the scutum, referred to as mesoscutum, and the "basal area of propodeum", here the metapostnotum, following Brothers (1976). The following abbreviations are used: F1-F11 for the flagellomeres; T1-T6, metasomal terga; and S1-S8, metasomal sterna. The punctation density is described in relation to the interspaces between punctures, measured in terms of puncture diameter (pd). The information provided between quotation marks in the type material section is an exact transcription of the label associated with the specimen; the inverted bars $(\backslash)$ indicate different lines in the same label. The holotype is deposited in the Coleção Entomológica Padre Jesus Santiago Moure, Departamento de Zoologia, Universidade Federal do Paraná, Curitiba, Brazil (DZUP).

\section{TAXONOMY}

\section{Xenochlora meridionalis sp. nov.}

http://zoobank.org/F2EB6601-DF3A-40B2-926F-4A23AE2DEDD2 Figs $1-7$

Diagnosis. The new species resembles $X$. nigrofemorata and $X$. ianthina but differs from them in having a greenish brassy upper frons and vertex; an upper gena without metallic reflexes; wings covered with uniformly brown and denser pilosity; plumose pilosity on parocular area and sides of mesoscutum less ramified; punctation on lower half of gena, adjacent to eye orbit, finer and sparser; shallow concavity of upper gena with striation relatively weak and restricted to portion adjacent to vertex and not as developed as striation on anterior corners of mesoscutum; central portion of mesoscutal disc, in the area devoid of metallic luster, with relatively finer and sparser punctation; and disc of T2 with denser punctation, punctures separated by 1-2 pd and about as coarse as those on marginal zone.

Description. Holotype female. Approximate body length: $9.0 \mathrm{~mm}$; maximum head width: $3.15 \mathrm{~mm}$; intertegular distance: $2.25 \mathrm{~mm}$; forewing length, including tegula: $8.4 \mathrm{~mm}$. Integumental Color. Mostly pale ferruginous, with greenish golden reflexes on clypeus, lower frons, gena, and mesosoma; upper frons, vertex, anterior one-fourth, lateral thirds and a narrow band along posterior margin of mesoscutum metallic greenish brassy to bronze. Antennae, tibiae and basitarsi of mid and hindlegs mostly ferruginous to light reddish-brown; apex of mandibles black. Wing membrane hyaline; veins and pterostigma pale reddish-brown to brown. Terga mostly ferruginous, with darker marginal zones, edge of T1-T4 reddish-brown. Pubescence. Mostly pale yellow; upper frons, vertex and most of mesoscutum with reddish-brown to brown pubescence; long erect setae on scutellum and metanotum mostly ferruginous to reddish-brown. Posterior surface and lower outer surface of midtibia, most of outer surface and basal third of inner surface of midbasitarsus, apex of femur, entire tibia except for reddish-brown plumose setae on basal half of its anterior margin, and most of basitarsus of hind leg with conspicuous dark brown to black setae; setae on inner surface of fore tibia, tarsi of fore and mid legs, outer apex and most of inner surface of basitarsus and entire distitarsus of hind leg mostly bright reddish-brown; mesotibial comb mostly reddish-brown with a few black simple setae on posterior basal edge. Wing microtrichia uniformly dark brown to black, relatively sparse on basal two-thirds of wings, distance between them about as long as microtrichium length. Short plumose pubescence on lower parocular area and lateral portions of disc of mesoscutum distinctly less plumose than that on anterior corner of mesoscutum. Tergal pilosity mostly dark brown to black, including that on lateroventral portions of sclerites; erect pilosity on anterior vertical portion of $\mathrm{T} 1$ and pilosity bordering medial cleft of T5 pale orange; lateroventral portions of terga with some orange erect setae; S1-S4 with pale yellow pubescence; S5 with mostly orange setae and some intermingled brown setae; tuft on apex of S6 orange. Integumental surface. Punctation on lower half of gena, adjacent to eye orbit, very fine and relatively sparse, punctures separated by $2-4 \mathrm{pd}$; shallow concavity of upper gena with coarser and denser punctation, its striation relatively weak and restricted to portion adjacent to vertex and not as developed as striation on anterior corners of mesoscutum; longitudinal striation radiating from posterior mandibular condyle well developed and distinctly stronger than that on concavity of upper gena; central portion of mesoscutal disc, in the area devoid of metallic luster, with relatively fine and sparse punctation, punctures separated by $3-5 \mathrm{pd}$; carinae on basal area of metapostnotum well-marked, medial carina strongest and lateral ones becoming progressively weaker; punctation on disc of $\mathrm{T} 2$ relatively dense, punctures separated by 1-2 pd and about as coarse as those on marginal zone.

Structure and measurements (in mm). Head slightly wider than long (3.17:2.91); labral elevation relatively broad, about $2.5 \mathrm{x}$ wider than long (0.35:0.14); clypeus about $3.7 \mathrm{x}$ wider than long (2.34:0.63); length of subantennal suture about $1.4 \mathrm{x}$ interalveolar distance (0.54:0.38) and slightly shorter than alveolo-orbital distance (0.54:0.60); length of scape, including radicle, shorter than distance between clypeus and mid ocellus (1.42:1.55); distance between posterior ocelli subequal to ocello-orbital distance (0.44:0.47); genal spine well developed and pointed (Fig. 5). Lateral corner of pronotal collar forming a slightly acute angle (Fig. 6); length of mesoscutum about $0.75 \mathrm{x}$ 


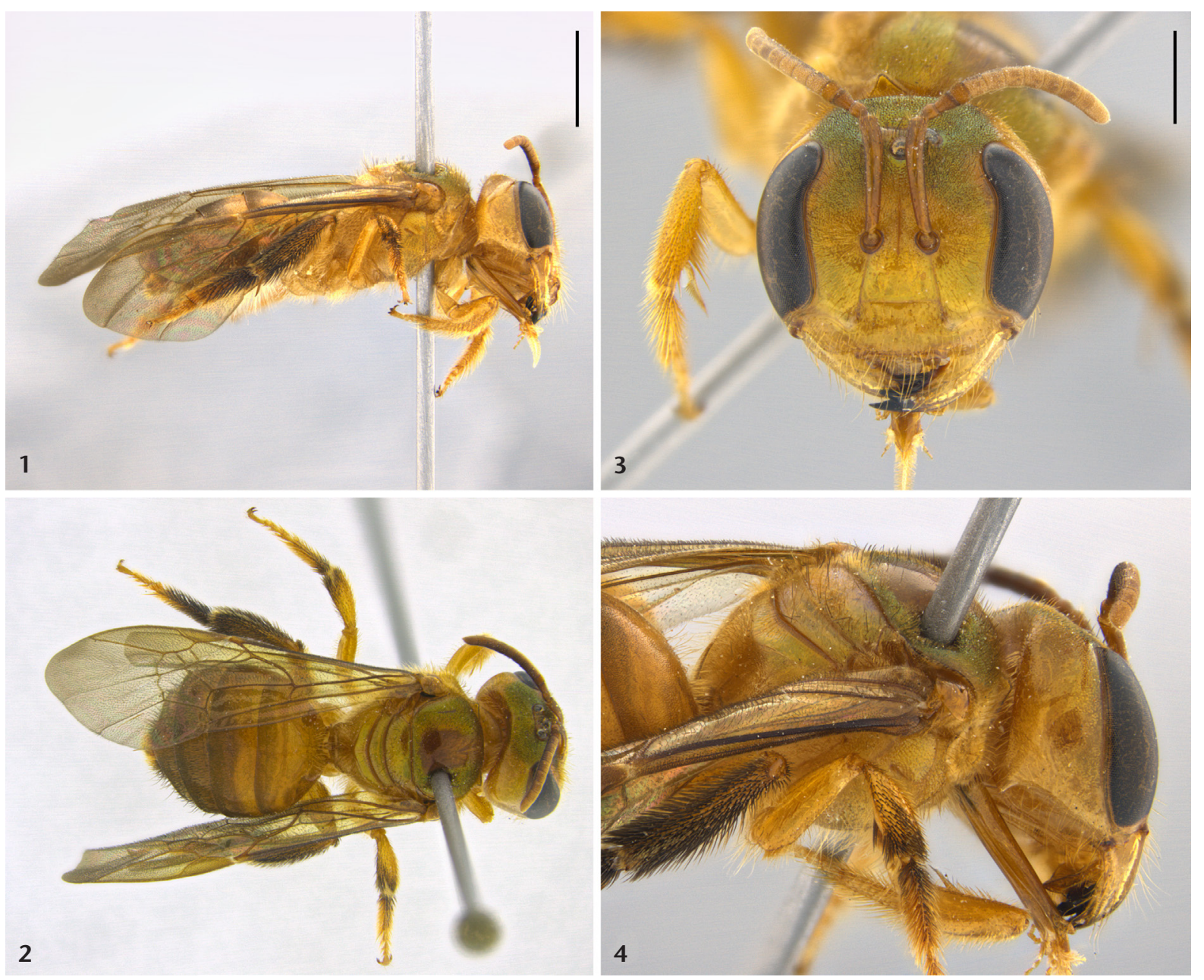

Figures 1-4. Xenochlora meridionalis sp. nov., female holotype: (1) Habitus, lateral view; (2) Habitus, dorsal view; (3) Head, frontal view; (4) Head and mesosoma, posterodorsal view. Scale bars: $1-2=2 \mathrm{~mm}, 3-4=1 \mathrm{~mm}$.

the intertegular distance (1.68:2.22); length of scutellum, along midline, about $1.7 \mathrm{x}$ the metanotum length (0.63:0.38); distal hamuli arranged as 3-1-1-1-1-3; inner spur of hind tibia with five teeth in addition to apex.

Type material. Holotype female, "BRA: ES, Linhares Reserva \Vale \23.24.iii.2013\2000m/replica 3/vanilina \L.R.R. Faria e eq. col." (DZUP).

Etymology. The new species is named for being the southernmost taxon in the genus Xenochlora, from the Latin meridionalis, meaning "southern".

\section{DISCUSSION}

The occurrence of Xenochlora meridionalis sp. nov. in the Atlantic forest supports the already well-established pattern of disjunct distributions between this forest formation of eastern Brazil and the Amazon basin for some plants and animals (e.g.,
Vanzolini and Williams 1970, Costa 2003, Martini et al. 2007, Fiaschi and Pirani 2009, Salles et al. 2010, Tonini et al. 2010, Batalha-Filho et al. 2013). Past connections between Amazon and Atlantic forests through central areas of South America are highly supported by independent evidence (e.g., Auler et al. 2004, Wang et al. 2004, Sobral-Souza et al. 2015).

In addition to the distributional pattern of Xenochlora, other bees also provide good examples of disjunct taxa where the Atlantic morphs closely resemble their Amazonian counterparts. Orchid bees (Apidae, Euglossini) deserve special attention in this scenario when taking into consideration the following reasons (i) they are closely related to forested areas (e.g., Dressler 1982), (ii) they are well sampled when compared to other groups of bees, mainly in the Atlantic forest (e.g., Sydney et al. 2010), and (iii) there have been recent revisions at species level for the fauna (e.g., Nemésio 2009, Faria and Melo 2012). Some examples where a species inhabits the Amazon Basin and its putative 

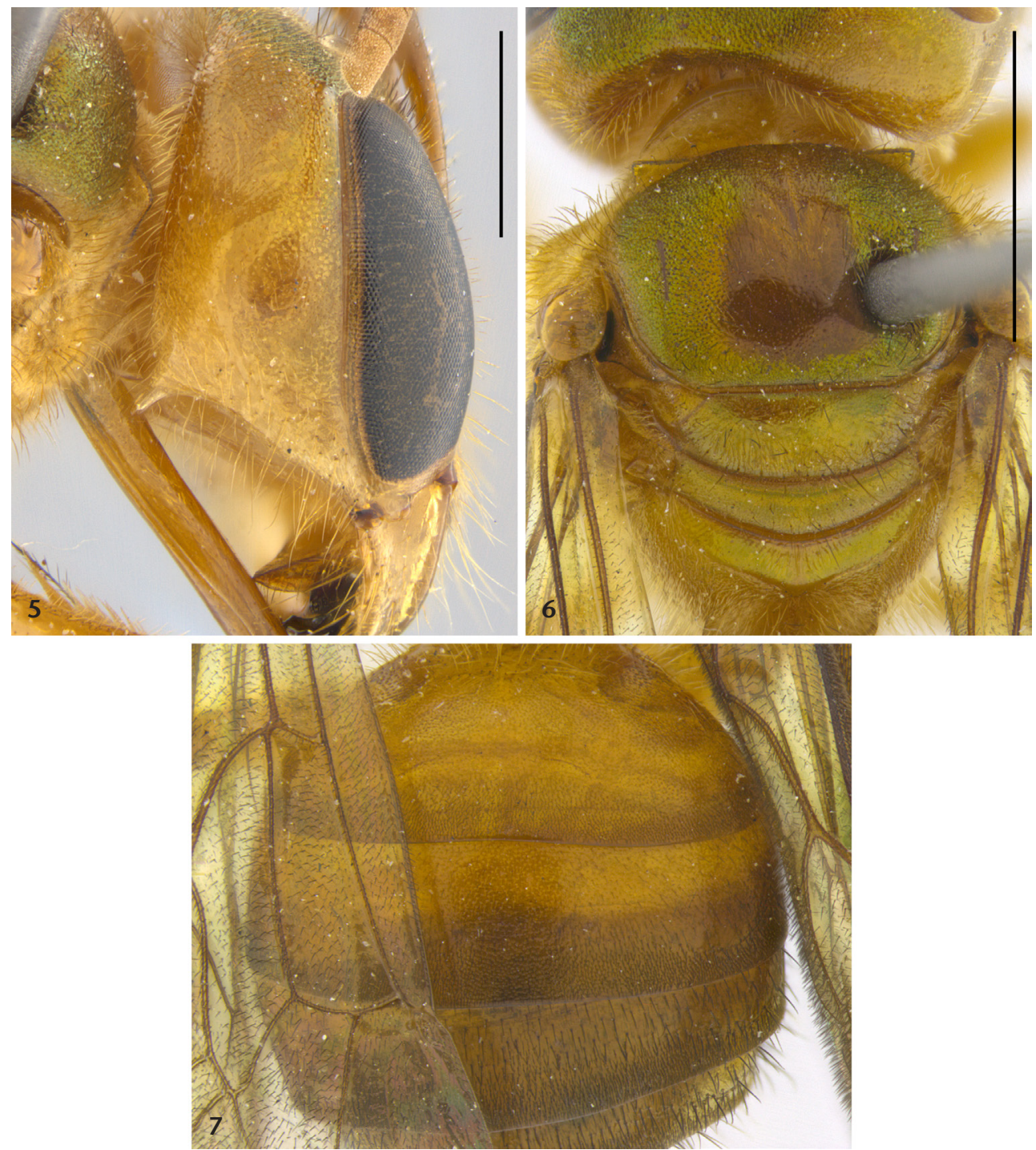

Figures 5-7. Xenochlora meridionalis sp. nov., female holotype: (5) Head, lateral view; (6) Mesosoma, dorsal view; (7) Metasoma, dorsal view. Scale bars: $5=1 \mathrm{~mm}, 6-7=2 \mathrm{~mm}$.

sibling is found in the Atlantic forest include (i) Euglossa parvula Dressler, 1982 and Eg. pepei Nemésio \& Engel, 2012, (ii) Eufriesea ornata (Mocsáry, 1896) and Ef. atlantica Nemésio, 2008, and (iii) Exaerete trochanterica (Friese, 1900) and Ex. salsai Nemésio, 2011. It is important to highlight that phylogenetic analyses and divergence times of these pairs of species are not available, so their closer relationship is hypothesized based only in the taxonomic interpretations of the authors. But phylogenetically supported evidence also exists. When studying the phylogeography of some species of Eulaema Lepeletier, 1841, López-Uribe et al. (2014) found that the individuals from Atlantic forest are closely related to their counterparts in the Amazon Basin from both species complexes involving respectively Eulaema meriana
(Olivier, 1789) and Eulaema bombiformis (Packard, 1869). They also found that the separation between the Amazonian and Atlantic forms are somewhat recent, ca. 1.0-2.0 Mya in both species complexes.

Nonetheless, unlike the examples presented above, the distribution patterns of some other bee taxa raise the following question: why some Amazonian groups have never crossed the forest bridges? It is remarkable in this context of faunal exchange that some particular genera of stingless bees as Aparatrigona Moure, 1951, Duckeola Moure, 1944, Nogueirapis Moure, 1953 and Ptilotrigona Moure, 1951, cleptoparasites as Aglae Lepeletier \& Serville, 1825 and Aglaomelissa Snelling \& Brooks, 1985 and other solitary bees as Xylocopa (Xylocopina) Hurd \& Moure, 1963 
have not been found in the Atlantic forest. Finding an answer to this question is certainly not a simple task, but the bionomics and phylogeny of taxa with disjunct or restricted distribution, both in Amazon basin or Atlantic forest, may shed light on the relation between past environmental filters and the functional traits of species with these distributional patterns. In this sense, the pattern exhibited by the stingless bees, whose newly founded nests depend of a nearby mother nest during their early beginning, suggests that the bridges between the Atlantic and Amazonian forests probably formed a fragmented landscape and not broadly continuous forested areas.

The southeastern-northwestern bridge (SE-NW; Bigarella et al. 1975) was proposed based on the distribution of taxa that inhabit western Amazonia and southeastern Atlantic Forest but not northeastern areas of this latter formation (e.g., Costa 2003) and have been regarded as the most important route between these forested biomes (Por 1992). This route seems to be the most ancient connection between southeastern Atlantic and Amazon forests and was established since the Andean uplift and the formation of the South American monsoon system (Ledo and Colli 2017). Batalha-Filho et al. (2013) presented data supporting two distinct pathways connecting both biomes, (i) more ancient connections (middle to late Miocene) through the current southern Cerrado and Mato Grosso and the transition towards the Chaco and palm savannas of Bolivia and Paraguay, and (ii) more recent connections (Pliocene and Pleistocene) through drier formations (Cerrado and Caatinga) in northeastern Brazil. Molecular dating of splits between sister lineages (one in Amazon and one in Atlantic forest) suggests the events related to the SE-NW bridge are more frequent and older than those related to the NE route (Ledo and Colli 2017).

Xenochlora meridionalis sp. nov. brings a new piece to the Amazon-Atlantic forest connection puzzle, and we hypothesize that Xenochlora reached the Atlantic forest through the SE-NW bridge, since so far it has been collected only in eastern Brazil. Considering the recent discovery of Aglae in forest fragments in Goiás, central Brazil (Silva et al. 2015), it is possible that more intensive sampling in this region may reveal the southernmost records for Amazonian species of Xenochlora. Furthermore, the general morphological similarity between Xenochlora meridionalis sp. nov. and their Amazon counterparts (mainly X. nigrofemorata and $X$. ianthina) suggests that the occurrence of this bee genus in the Atlantic Forest derives from a more recent faunal exchange, in the same way as with several pairs of species of orchid bees, dated from the late Pliocene-Pleistocene (see molecular dating of euglossine evolution in Ramírez et al. 2010 and López-Uribe et al. 2014).

\section{ACKNOWLEDGMENTS}

We acknowledge Maria Cecília Martins Kierulff for all the support during fieldwork, and Vale company/Reserva Natural Vale administration for allowing us to sample the bees of the preserve. J.A. Coswosk, E.D.G. Soares, R.A. Ferreira, A. Storari and F.F. Salles are acknowledged for all the help with fieldwork. We also thank Eduardo A.B. Almeida and Ângelo P. Pinto for reviewing the manuscript and for suggestions that helped improve it. SISBIO/ ICMBio is acknowledged for the provided collecting permit (\#21803). Partial support has been provided by the Conselho Nacional de Desenvolvimento Científico e Tecnológico (CNPq 309641/2016-0) to GARM. All authors revised the text and are solely responsible for accuracy in use of the English language.

\section{LITERATURE CITED}

Amorim HB (1984) Florestas nativas dos estados do Rio de Janeiro e Espírito Santo. Instituto Brasileiro do Desenvolvimento Florestal-IBDF, Brasilia, 204 pp.

Auler AS, Wang A, Edwards RL, Cheng H, Cristalli PS, Smart ML, Richards DA (2004) Quaternary ecological and geomorphic changes associated with rainfall events in presently semi-arid northeastern Brazil. Journal of Quaternary Science 19(7): 693-701. https://doi.org/10.1002/jqs.876

Batalha-Filho H, Fjeldså J, Fabre P-H, Miyaki CY (2013) Connections between the Atlantic and the Amazonian forest avifaunas represent distinct historical events. Journal of Ornithology 154(1): 41-50. https://doi.org/10.1007/s10336-012-0866-7

Bigarella JJ, Andrade-Lima D, Riehs PJ (1975) Considerações a respeito das mudanças paleoambientais na distribuição de algumas espécies vegetais e animais no Brasil. Anais da Academia Brasileira de Ciências 47(Supl.): 411-464.

Brothers DJ (1976) Modifications of the metapostnotum and origin of the "propodeal triangle" in Hymenoptera Aculeata. Systematic Entomology 1(3): 177-182. https://doi. org/10.1111/j.1365-3113.1976.tb00036.x

Costa LP (2003) The historical bridge between the Amazon and the Atlantic Forest of Brazil: a study of molecular phylogeography with small mammals. Journal of Biogeography 30(1): 71-86. https://doi.org/10.1046/j.1365-2699.2003.00792.x

Coswosk JA, Ferreira RA, Soares EDG, Faria LRR (2018) Responses of euglossine bees (Hymenoptera, Apidae, Euglossina) to an edge-forest gradient in a large Tabuleiro forest remnant in eastern Brazil. Neotropical Entomology 47(4): 447-456. https://doi.org/10.1007/s13744-017-0533-z

Dressler RD (1982) Biology of the orchid bees (Euglossini). Annual Reviews of Ecology and Systematics 13: 373-394. https://doi.org/10.1146/annurev.es.13.110182.002105

Eickwort GC (1969) A comparative morphological study and generic revision of the augochlorine bees (Hymenoptera: Halictidae). University of Kansas Science Bulletin 48: 325-524.

Engel MS (2000) Classification of the bee tribe Augochlorini (Hymenoptera: Halictidae). Bulletin of the American Museum of Natural History 250: 1-89. http://hdl.handle.net/2246/1598

Engel MS (2006) A new nocturnal bee of the genus Megalopta, with notes on other Central American species (Hymenoptera: Halictidae). Mitteilungen des Internationalen Entomologischen Vereins 31: 37-49. 
Engel MS, Brooks RW, Yanega D (1997) New genera and subgenera of augochlorine bees (Hymenoptera: Halictidae). Scientific Papers of the Natural History Museum of the University of Kansas 5: 1-21. https://doi.org/10.5962/bhl.title.4042

Faria LRR, Melo GAR (2012) Species of Euglossa of the analis group in the Atlantic forest (Hymenoptera, Apidae). Zoologia 29(4): 349-374. https://doi.org/10.1590/S198446702012000400008

Fiaschi P, Pirani JR (2009) Review of plant biogeographic studies in Brazil. Journal of Systematics and Evolution 47(5): 477496. https://doi.org/10.1111/j.1759-6831.2009.00046.x

Gonçalves RB (2016) A molecular and morphological phylogeny of the extant Augochlorini (Hymenoptera, Apoidea) with comments on implications for biogeography. Systematic Entomology 41(2): 430-440. https://doi.org/10.1111/ syen. 12166

Ledo RMD, Colli GR (2017) The historical connections between the Amazon and the Atlantic Forest revisited. Journal of Biogeography 44(11): 2551-2563. https://doi.org/10.1111/ jbi.13049

Lopes JC, de Mello-Silva R (2014) Annonaceae da Reserva Natural Vale, Linhares, Espírito Santo. Rodriguésia 65(3): 599_ 635. https://doi.org/10.1590/2175-7860201465304

López-Uribe MM, Zamudio KR, Cardoso CF, Danforth BN (2014) Climate, physiological tolerance and sex-biased dispersal shape genetic structure of Neotropical orchid bees. Molecular Ecology 23(7): 1874-1890. https://doi. org/10.1111/mec.12689

Martini AMZ, Fiaschi P, Amorim AM, Paixão JM (2007) A hotpoint within a hot-spot: a high diversity site in Brazil's Atlantic Forest. Biodiversity Conservation 16(11): 3111-3128. https://doi.org/10.1007/s10531-007-9166-6

Michener CD (2007) The Bees of the World. Johns Hopkins, Baltimore, $2^{\text {nd }}$ ed., $953 \mathrm{pp}$.

Nemésio A (2009) Orchid bees (Hymenoptera: Apidae) of the Brazilian Atlantic Forest. Zootaxa 2041: 1-242.

Nemésio A, Santos Júnior JE, Buys SC (2016) A fauna de abelhas e vespas apoideas (Hexapoda: Hymenoptera: Apoidea) da Reserva Natural Vale, norte do Espírito Santo. In: Rolim SG, Menezes LFT, Srbek-Araujo AC (Eds) Floresta Atlântica de Tabuleiro: diversidade e endemismos na Reserva Natural Vale. Rupestre, Belo Horizonte, 329-340.

Peixoto AL, Silva IM, Pereira OJ, Simonelli M, Jesus RM, Rolim SG (2008) Tabuleiro forests north of the Rio Doce: their representation in the Vale do Rio Doce Natural Reserve, Espírito Santo, Brazil. In: Thomas WW (Ed) The Atlantic coastal forest of northeastern Brazil. The New York Botanical Garden Press, New York, 319-350.

Por FD (1992) Sooretama: the Atlantic rain forest of Brazil. SPB Academic, The Hague, $130 \mathrm{pp}$.

Ramírez SR, Roubik DW, Skov C, Pierce NE (2010) Phylogeny, diversification patterns and historical biogeography of euglossine orchid bees (Hymenoptera: Apidae). Biological
Journal of the Linnean Society 100(3): 552-572. https://doi. org/10.1111/j.1095-8312.2010.01440.x

Rolim SG, Magnago LFS, Saiter FZ, Amorim AM, Abreu KMP (2016) São as florestas do norte do Espírito Santo e sul da Bahia as mais ricas em espécies arbóreas no domínio da Floresta Atlântica? In: Rolim SG, Menezes LFT, Srbek-Araujo AC (Eds) Floresta Atlântica de Tabuleiro: diversidade e endemismos na Reserva Natural Vale. Rupestre, Belo Horizonte, 91-100.

Salles FF, Nascimento J, Massariol F, Angeli K, Barcelos-Silva P, Rúdio J, Boldrini R (2010) First survey of mayflies (Ephemeroptera, Insecta) from Espírito Santo state, southeastern Brazil. Biota Neotropica 10(1): 293-307. https://doi. org/10.1590/S1676-06032010000100025

Santos LM, Melo GAR (2013) Taxonomic notes and description of the male of Xenochlora nigrofemorata (Smith, 1879) (Hymenoptera: Apidae: Halictinae). Zootaxa 3670: 371-377.

Silva AG (2014) A importância da Reserva Natural Vale para a conservação das florestas tropicais nativas do Norte do Espírito Santo, Brasil. Natureza Online 12(5): 206-211. http:// www.naturezaonline.com.br/natureza/conteudo/pdf/02_ SilvaAG_206-211.pdf

Silva DP, Varela S, Nemésio A, de Marco P Jr (2015) Adding biotic interactions into paleodistribution models: a host-cleptoparasite complex of Neotropical orchid bees. Plos One 10: e0129890. https://doi.org/10.1371/journal.pone.0129890

Smith F (1861) Descriptions of new genera and species of exotic Hymenoptera. Journal of Entomology 1: 146-155.

Sobral-Souza T, Lima-Ribeiro MS, Solferini VN (2015) Biogeography of Neotropical Rainforests: past connections between Amazon and Atlantic Forest detected by ecological niche modeling. Evolutionary Ecology 29(5): 643-655. https:// doi.org/10.1007/s10682-015-9780-9

Sydney NV, Gonçalves RB, Faria LRR (2010) Padrões espaciais na distribuição de abelhas Euglossina (Hymenoptera, Apidae) da região Neotropical. Papéis Avulsos de Zoologia 50(43): 667-679. https://doi.org/10.1590/S003110492010004300001

Tierney SM, Gonzales-Ojeda T, Wcislo WT (2008) Nesting biology and social behavior of Xenochlora bees (Hymenoptera: Halictidae: Augochlorini) from Peru. Journal of the Kansas Entomological Society 81(1): 61-72. https://doi. org/10.2317/JKES-704.24.1

Tierney SM, Sanjur O, Grajales GG, Santos LM, Bermingham E, Wcislo WT (2012) Photic niche invasions: phylogenetic history of the dim-light foraging augochlorine bees (Halictidae). Proceedings of the Royal Society of London B 279(1729): 794-803. https://doi.org/10.1098/rspb.2011.1355

Tonini JFR, Carão LM, Pinto IS, Gasparini JL, Leite YLR, Costa LP (2010) Non-volant tetrapods from Reserva Biológica de Duas Bocas, state of Espírito Santo, southeastern Brazil. Biota Neotropica 10(3): 339-351. http://dx.doi.org/10.1590/ S1676-06032010000300032 
Vanzolini PE, Williams EE (1970) South American Anoles: The geographic differentiation and evolution of the Anolis chrysolepis species group (Sauria, Iguanidae). Arquivos de Zoologia 19(3-4): 1-124. https://doi.org/10.11606/issn.21767793.v19i3-4p125-298

Veloso HP, Rangel ALR, Lima JCA (1991) Classificação da vegetação brasileira, adaptada a um sistema universal. IBGE-DERMA, Rio de Janeiro, 124 pp.

Wang XF, Auler AS, Edwards RL, Cheng H, Cristalli PS, Smart PL, Richards DA, Shen CC (2004) Wet periods in northeastern Brazil over the past $210 \mathrm{kyr}$ linked to distant climate anomalies. Nature 432: 740-743. https://doi.org/10.1038/ nature03067
Submitted: February 11, 2019

Accepted: June 24, 2019

Available online: November 5, 2019

Editorial responsibility: Ângelo Parise Pinto

Author Contributions: GARM, LRRF and LMS planned the paper; LRRF and GARM wrote the manuscript, with contributions from LMS.

Competing Interests: The authors have declared that no competing interests exist.

(C) 2019 Sociedade Brasileira de Zoologia. Published by Pensoft Publishers at https://zoologia.pensoft.net 